\title{
Morpho-agronomic characteristics of valerian (Valeriana officinalis L.) derived from in-vitro culture
}

\author{
Siti Fatimah Syahid ${ }^{1 *}$, Hera Nurhayati $^{1}$, and Budi Hartoyo ${ }^{2}$ \\ ${ }^{1}$ Indonesian Spices and Medicinal Crops Research Institute, Bogor, Indonesia \\ ${ }^{2}$ Central Java Assessment Institute for Agricultural Technology, Indonesia
}

\begin{abstract}
Valeriana officinalis belongs to the Valerianaceae family, is a well-known herb and medicinal plant. Plant roots are commonly used as medicine by the pharmaceutical industry. Observation on morphoagronomic characteristics of valerian propagated in vitro is needed to determine their morphological characteristics and production in the field. The study aimed to observe the morphological characteristics of valerian derived from in vitro culture. The experiment was conducted at the Indonesian Spices and Medicinal Crops Research Institute (ISMCRI) Bogor, arranged in a Completely Randomized Design with three replications. Each replication consisted of ten individual plants. Valerian plantlets from in vitro culture were acclimatized in the greenhouse and planted in media composed of a mixture of soil, compost, and husk. Afterward, 3 months old valerian was then transferred into a polybag. The plants were harvested at 9 and 12 months after planting (MAP). Valerian plantlets from in vitro propagation were successfully acclimatized in the greenhouse. Furthermore, the morphological characteristics of the plant were similar to the parents. The yield was significantly higher at $12 \mathrm{MAP}$ than $9 \mathrm{MAP}$. The tissue culture technique was prospective for valerian propagation to support rapid plant material provision for seeds or raw material for the pharmaceutical industry.
\end{abstract}

\section{Introduction}

Valerian (Valerian. officinalis L.) is originally from Europe. Plant roots are commonly used as medicine by the pharmaceutical industry. Valerian root is a popular and widely available herbal supplement, primarily used to treat insomnia and anxiety [1]. Moreover, valerian is one of the best-selling drugs in Europe for a sedative. Valerian extracts are currently considered dietary supplements, primarily comprised of dried root or root extracts, formulated into tablets or soft gelatine capsules [2].

$V$. officinalis belongs to Valerianaceae family, is a well-known herb and medicinal plant [3]. The genus of Valerian comprises nearly 200 species, but $V$. officinalis L. is the only species that is most often used as a herbal medicine [4]. The known pharmacologically active compounds detected in valerian extracts are alkaloids, terpenes, organic acids, and its

* Corresponding author: fatimahsyahidsitti@gmail.com 
derivates, valepotriates, and flavones. Valepotriates are considered the main compounds responsible for the sedative activity of the Valerianaceae.

Valerian can be propagated either generatively by seed or vegetatively using tillers. However, the main problem in conventional propagation is disease attack [5]. Disease-free valerian planting materials can be obtained through in vitro propagation. The success of in vitro propagation is determined by various factors such as genotypes, growth media, the balance of plant growth regulator (PGR) used in the media, and the culture growth condition. The culture medium with an optimal supply and a suitable combination of PGR will increase the success of in vitro plant regeneration [6].

Micropropagation of valerian in vitro has been conducted at Indonesian Spices and Medicinal Crops Research Institutes (ISMCRI) using rhizome as an explants [7]. However, the morphological characteristics of the plants grown in the greenhouses have not been observed yet. Thus, the study aimed to observe the morphological characteristics of valerian derived from in vitro culture.

\section{Materials and methods}

The research was conducted at the greenhouse of ISMCRI Bogor (240 m asl), West Java, Indonesia. The planting material used was valerian plantlets derived from in vitro culture. Valerian plantlets were removed from culture bottles and washed to remove the agar (Figure 1a). The plantlets were then transferred into a small plastic cup containing sterile media (soil, compost, and husk), covered by a polyethylene bag to maintain the humidity (Figure 1b and c). The polyethylene bag was opened gradually at two weeks after transplantation, and in one month, it was removed entirely. The plants were maintained in the greenhouse for three months. The 3 month-old valerian was then planted in a $40 \mathrm{~cm}$ x $50 \mathrm{~cm}$ polybag filled with soil and manure $(2: 1)$ as growing media. The plants were maintained in the greenhouse until 5 months old and then relocated to the outside greenhouse. The plants were harvested at 9 and 12 months after planting (MAP).
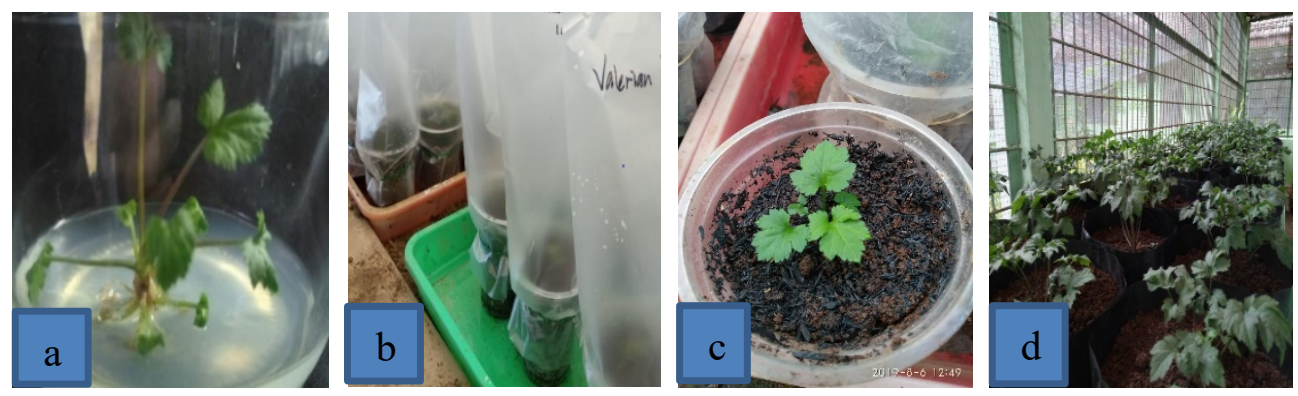

Fig. 1. Valerian acclimatization: a) valerian plantlets, b) acclimatized plants, c) one-month-oldacclimatized valerian, d) valerian at two months after planting.

The morphological characteristics observed were qualitative and quantitative characters of the stem (color, shape, size), leaf (color, shape, size), and root (color, shape, weight). All the quantitative characteristics were measured at 5, 9, and 12 MAP. Other parameters observed were plant growth (tillers number, plant height, length, width, and thickness of the leaf) and yield (fresh and dry weight of roots and root length). The plants were harvested twice at 9 and 12 MAP. Root fresh weight was measured after cleaning the roots from debris and soil, whereas root dry weight was quantified after drying up the roots for two days.

Qualitative characteristics such as the color of leaf, stem, leaf bone, and flower were identified using RHS (The Royal Horticultural Society) color chart. In addition, the plant morphological characteristics were determined following [8]. The parent plants were also 
observed their morphology characteristics visually as a control to evaluate the similarity with valerian plantlets derived from in vitro culture.

The experiment was arranged in Completely Randomized Design, two harvesting times, 9 and 12 MAP as the treatments, with three replications. Each replication consisted of 10 individual plants. The data were analyzed using Statistical Analysis System SAS Program (SAS software). Further testing was done using a T-test at 5\% level if the data were significantly different.

\section{Results and discussions}

The all acclimatized valerian plantlets grew normally. All the qualitative characteristics of valerian from in vitro culture were similar to their parent plants (Table 1, Figure 2 and 3). No phenotypic changes were detected during observation. Valerian had a compound leaf with a cordate shape and semi-rounded leaf stalks. Leaf tip was acuminate, whereas leaf base was cuneate. It also possessed compound flowers, rounded stems, and fibrous roots. New tillers emerged from the stem base both above and under the soil, forming new individuals. The stems grew upward. Valerian developed a very fine structured roots system. The more or less thick adventitious roots derived from the rhizome and the thinner lateral roots were interweaved to form a carped-like matted network [9].

Table 1. Morphological characteristics of valerian derived from in-vitro culture

\begin{tabular}{|c|c|c|}
\hline \multicolumn{3}{|c|}{ Morphological characteristics } \\
\hline \multicolumn{3}{|c|}{ Leaf : Shape } \\
\hline \multicolumn{2}{|c|}{ Lamina } & Cordate \\
\hline - & Apex & Acuminate \\
\hline - & Base & Cuneate \\
\hline & Type & Compound \\
\hline \multicolumn{2}{|c|}{ Margin } & Bisserate \\
\hline- & Venation & Net-veined \\
\hline- & Surface & Hairy \\
\hline \multicolumn{3}{|c|}{ Leaf : Color } \\
\hline- & Young leaf tip & Yellow green group/YGG $144 \mathrm{~B}$ \\
\hline- & Young leaf base & Yellow green group /YGG $144 \mathrm{D}$ \\
\hline - & Upper leaf surface & Green group GG $137 \mathrm{~A}$ \\
\hline- & Bottom leaf surface & Green group GG $138 \mathrm{~B}$ \\
\hline \multicolumn{3}{|c|}{ Stem } \\
\hline- & Shape & Round \\
\hline - & Growth & Upper Straight \\
\hline- & Colour & $\begin{array}{l}\text { Green group GG } 143 \text { B dan Purple } \\
\text { green/ PG N79 B }\end{array}$ \\
\hline \multicolumn{3}{|c|}{ Flower } \\
\hline- & Type & Compound \\
\hline- & Colour & White group/ WG N $155 \mathrm{~A}$ \\
\hline \multicolumn{3}{|c|}{ Root } \\
\hline- & Type & Fibrous \\
\hline- & Colour & Greyed orange group /GOG 167 C \\
\hline
\end{tabular}



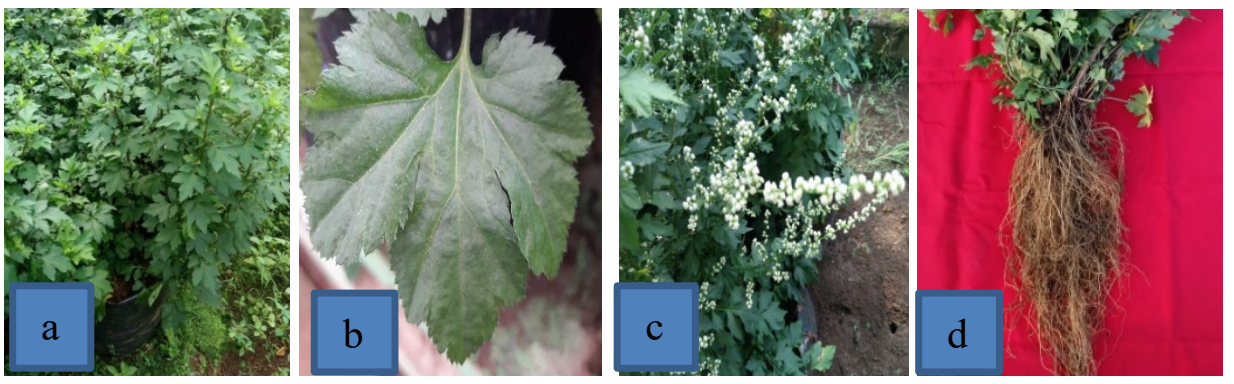

Fig. 2. Morphological characteristics of valerian derived from in vitro culture a) habitus, b) leaf, c) flower and d) root.


Fig. 3. Morphological characteristics of valerian parent plant: a) habitus, b) leaf, c) flower, d) roots.

Valerian from in vitro culture possessed similar morphology as the parent plant because the explant sources for in vitro propagation were from vegetative parts/rhizome [7]. Plant propagation through in vitro culture using vegetative explant as sources material will produce similar planting material as the parents as long as using PGR in a low concentration, especially Benzyl adenine (BA). However, genetic variation could occur in undifferentiated cells (callus phase), isolated protoplast, tissues, and morphological traits of in vitro raised plants. It can be induced by many factors such as PGR, explants source, subculture period, and also culture condition $[10,11,12]$.

In this research, the BA was used at a low concentration of $0.1 \mathrm{mg} . \mathrm{L}^{-1}[7]$, and valerian plantlets were cultured in a short period. The longer the culture period, the greater the somaclonal variation [13]. Valerian derived from in vitro culture showed no phenotypic changes. This characteristic indicated that valerian could be mass-propagated through in vitro culture. The uniformity of individual plants within a clone population was a major advantage of clonal cultivars in commercial production [14]. Valerian propagated through direct organogenesis from leaf segments also showed no phenotypic variations [15].

Quantitative morphological characteristics of valerian were presented in Table 2. The growth of valerian was accelerated after plants were re-planted into large polybags containing planting media. Greater volume of planting media supported better root development by improving the absorption of nutrients and water [16]. At the early stage, the plants grew slowly due to the adaptation process in the greenhouse. However, all of the growth components increased significantly at 9 MAP (Table 2). Therefore, valerian was potential to be mass-propagated through in vitro culture to provide rapid planting materials. 
Table 2. The growth of valerian derived from in vitro culture, at 5 and 9 months after planting

\begin{tabular}{|c|c|c|}
\hline \multirow{2}{*}{ Growth characters } & \multicolumn{2}{|c|}{ Age (months after planting) } \\
\cline { 2 - 3 } & 5 & 9 \\
\hline Number of tillers & 2.0 & $13.1^{*}$ \\
\hline Plant height $(\mathrm{cm})$ & 14.4 & $78.2^{*}$ \\
\hline Leaf length $(\mathrm{cm})$ & 6.2 & $11.7^{*}$ \\
\hline Leaf width $(\mathrm{cm})$ & 3.8 & $8.2^{*}$ \\
\hline Leaf thickness $(\mathrm{mm})$ & 0.1 & $0.2^{*}$ \\
\hline
\end{tabular}

Note: * Significantly different at $5 \% \mathrm{~T}$ test.

Harvesting time affected root length and root dry weight significantly. Plants harvested at 12 MAP had longer root length and higher root weight than 9 MAP (Tabel 3). The root fresh weight at 9 MAP was $128.3 \mathrm{~g} / \mathrm{plant}$, which was equivalent to $7 \mathrm{t} / \mathrm{ha}$, and it was similar to those from conventional cultivation (7-9 t/ha at 9 MAP) [17]. The root dry weight was significantly increased at 12 MAP (43.3 g/plant) (Table 3).

Table 3. The yield of valerian derived from in vitro culture at 9 and 12 months after planting

\begin{tabular}{|c|c|c|}
\hline \multirow{2}{*}{ Yield component } & \multicolumn{2}{|c|}{ Harvesting time (months after planting) } \\
\cline { 2 - 3 } & 9 & 12 \\
\hline Root length $(\mathrm{cm})$ & 29.1 & $34.3^{*}$ \\
\hline Root fresh weight $(\mathrm{g} /$ plant $)$ & 128.3 & $120.8 \mathrm{~ns}$ \\
\hline Root dry weight $(\mathrm{g} /$ plant $)$ & 19.1 & $43.3^{*}$ \\
\hline
\end{tabular}

Note : ns : not significantly different at $1 \% \mathrm{~T}$ test $;{ }^{*}$ : significantly different at $1 \% \mathrm{~T}$ test

The root dry weight at $12 \mathrm{MAP}$ was similar to the Lubelski variety (46.3 g/plant) [18]. This might relate to the root tissue's water content, which decreased in the older plants, hence enhancing their root dry weight. The result suggested that the suitable harvesting time was at 12 MAP to get a high root yield.

\section{Conclusion}

Valerian derived from in vitro culture could be acclimatized and grown well in the greenhouse. Visually, the morphological characteristic of valerian propagated in vitro was similar to their parent plants. Moreover, the appropriate harvesting time was at 12 MAP to get the high root yield. Thus, the in vitro propagation of valerian was potentially developed to support rapid plant material provision for seeds or as raw material for the pharmaceutical industry.

Acknowledgement. The authors would like to thank the Indonesian Spices and Medicinal Crops Research Institute (ISMCRI), Indonesian Agency for Agricultural Research and Development (IAARD), for funding the research. Special thanks to Ragapadmi Purnamaningsih (ICABGRRDIAARD)for comments and suggestions, Dewi Yulianti, Totong Sugandi, and Mariana Susilowati (ISMCRI-IAARD) for their contribution in the laboratory and greenhouse works and conducting statistical data analysis.

\section{References}

1. K. Murphy, Z.J. Kubin, J.N. Shepherd, R.H. Ettinger, Phytomedicine. 17, 674 (2010)

2. J. Patočka, J. Jakl, J. Appl. Biomed. 8, 11 (2010)

3. S.A. Pilerood, J. Prakash, Int. J. Food, Nutr. Diet. 1, 25 (2013)

4. M. Sharma, U.K. Jain, A. Patel, N. Gupta, Int. J. Pharma. Sci. Res. 1, 6 (2010) 
5. R. Janke, A Grower's Guide Valerian (Valeriana officinalis) (Kansas, 2004)

6. M.L.P.D. Oliveira, M.G.C. Costa, C.V.D. Silva, W.C. Otoni, Pesqui. Agropecuária. Bras. 45, 654 (2010)

7. S.F. Syahid, Shoot multiplication and roots induction of valerian (Valeriana officinalis L) in vitro through Benzyl Amino Purin and Indol Butyric Acid Application, in Proceeding of PERIPI-2017 International Seminar, October $2^{\text {nd }} 2017$, PERIPI (Indonesian Breeding Science Society) Department of Agronomy and Horticulture, Faculty of Agriculture, Bogor Agricultural University, Bogor, Indonesia (2018)

8. G. Tjitrosoepomo, Morfologi Tumbuhan (Gajah Mada University Press, Yogyakarta, 2016)

9. M. Penzkofer, Breeding support for Valeriana officinalis L. sl: root structure, localization of value-determining secondary compounds and mating behavior at open pollination, (Doctoral dissertation, Hannover: Institutionelles Repositorium der Leibniz Universität Hannover, 2019)

10. M.W. Bairu, A.O. Aremu, J. Van Staden, Plant Growth Regul. 63, 147 (2011)

11. L. Currais, J. Loureiro, C. Santos, J.M. Canhoto, Plant Cell. Tissue Organ. Cult. 114, 149 (2013)

12. M.J.M. Smulders, G.J. De Klerk, Plant. Growth. Regul. 63, 137 (2011)

13. X. Gao, D. Yang, D. Cao, M. Ao, X. Sui, Q. Wang, J.N. Kimatu, L. Wang, J. Plant. Growth. Regul. 29, 257 (2010)

14. H. Krishna, M. Alizadeh, D. Singh, U. Singh, N. Chauhan, M. Eftekhari, R.K. Sadh, 3 Biotech. 6, 54 (2016)

15. G.H. Abdi, M. Khosh-Khui, Int. J. Agric. Res. 2, 877 (2007)

16. T.M. Onggo, K. Kusumiyati, A. Nurfitriana, Kultivasi. 16, 298 (2017)

17. H. Nurhayati, R. Muljati, N. Maslahah, Budidaya tanaman introduksi valerian (Valeriana officinalis L.), in Prosiding Seminar Nasional dan Pameran Pengembangan Tanaman Obat Menuju Kemandirian Masyarakat Dalam Pengobatan Keluarga, Balai Penelitian Tanaman Obat dan Aromatik, Jakarta (2006)

18. J. Wiśniewski, M. Szczepanik, B. Kołodziej, B. Król, J. Anim. Plant Sci. 26, 177 (2016) 